\title{
THE DEVELOPMENT OF CIVIC COMPETENCIES AT SECONDARY LEVEL THROUGH SERVICE-LEARNING PEDAGOGIES
}

\section{INTRODUCTION}

Recent years have seen increasing interest in ensuring that students at all levels in the educational system may acquire broader interpersonal and civic competencies beyond the technical and/or discipline-specific knowledge that has traditionally been valued. This article discusses the emergence of secondary level as an appropriate space for such "citizenship" or "civic" education. Hence, the possibility of developing the intellectual and social competencies associated with citizenship or civic-mindedness at that level is explored. This issue is first addressed in general terms; then we present an experiential pedagogy known as Service-Learning (SL), which has been growing in popularity as an effective approach for achieving the learning outcomes (e.g. knowledge, skills, attitudes) that enable participation in a democratic society. Later, two programs based on this methodology which are applicable to this level of education are presented. After analysis and evaluation of these programs, we appraised the suitability of Service-Learning for the development of civic competencies in secondary education students, the citizens and professionals of the XXI century.

\section{THE EMERGENCE OF CIVIC COMPETENCIES IN SECONDARY EDUCATION}

The term "competencies" has been widely discussed in recent years (Boyatzis, 1982; Hoskins and Crick, 2010; Lange, Print, Hoskins, et all, 2011; Le Boterf, 1993; Levy-Leboyer, 1997; Jover, Fernández-Salinero and Ruiz Corbella, 2005; Sarramona, Domínguez, Noguera and Vázquez, 2005). Bearing in mind the variety of frameworks in which it is used, from psychology to business, and in the field of education, "competencies" may be defined as "observable and habitual behaviors which enable the individual's success in their activity" (Cardona and Chinchilla, 1999; Woodrufe, 1993) ${ }^{1}$.

Nowadays, use of the term "competencies" has spread through all sectors which have some form of educational prerogative, not only formal education centers, but also non-formal learning institutions such as business organizations. In the business 
sector, competence management is used as a means by which individuals may be selected for employment, as well as educated and trained (Alles, 2008 and 2000; Pereda, 2006). The term has also been adopted in a range of institutions whose specific function is teaching. In fact, in the field of higher education, degree program contents and criteria are framed in terms of competencies (Bergen, 2005; London, 2007; Royal Decree 1393/2007). At previous levels in the education system, the school curriculum focuses on fostering the basic competencies every student needs to complete their compulsory schooling successfully. In this regard, many international, European and Spanish bodies have defined and described the contents of the basic competencies to be included in the school curriculum. An overview of such information is presented in Table 1:

Insert Table 1

These reports compile the various basic competencies to be acquired as part of compulsory schooling. Repeated reference is made to the social or civic competence. Each of these references is elucidated in further detail below ${ }^{2}$.

On the international stage, learning to live together is listed as one of the four pillars of education in the Delors Report drafted by UNESCO in 1996. The OECD project whose purpose was the Definition and Selection of Competencies (DeSeCo) includes the ability to relate to others, to cooperate, and to manage and resolve conflicts among the basic competencies, skills which comprise the social and civic competence as such (DeSeCo, 2003).

In the United States, the enGauge 21 $1^{\text {st }}$-century Skills report (NCREL, 2001) defined student competence in personal, social and civic responsibility as a basic skill. Partnership for 21st Century Skills (2003) highlighted civic competence and civic literacy in its list of essential $21^{\text {st }}$-century subjects and topics.

The European Union's Tuning Project sets out a framework of general competencies designed to shape educational reform. Interpersonal competencies, which play a key role in civic competence as such (González and Wagenaar, 2003), are the most highly rated by academics, employers and university graduates. In addition, in the Recommendation of Key Competencies for Lifelong Learning (Official Journal of the European Union, 2006), the European Parliament and the Council of Europe define eight key competencies, one of which is social and civic competence.

The most recent legislation relating to this issue in Spain (the Organic Law on Education: LOE, 2006) establishes social and civic competence as a fundamental goal of compulsory education ${ }^{3}$.

In light of this overview of the initiatives taken at international, European and national levels, the following conclusion may be drawn: the mission of the educational system is not limited to the communication and integration of knowledge; it also encompasses the acquisition of basic competencies. The social and civic competence is especially significant in this regard. Thus, educational institutions must establish goals that go beyond the transmission of instrumental knowledge; their role in the education of future citizens must also be taken into account (Kerr, 2011). 
The definition and description of contents for such forms of competence may be very worthwhile in this context. Civic competence may be defined as preparing students to take part in democratic citizenship, encompassing two types of competence: the intellectual and the participative (Kerr, 2011; Lange, Print, Hoskins, et al, 2011; LOE, 2006, Preámbulo; Veldhuis, 1997 and Naval, 2000, 57).

Intellectual competencies enable students to think critically, helping them to become reflexive citizens capable of offering open and constructive criticism of the issues on which they reflect. Among other things, intellectual competencies enable the individual to see in a rational way the value of getting involved in social improvement. The following intellectual competence may be highlighted (Hoskins and Crick, 2010; NCREL, 2001; Partnership for 21st Century Skills, 2003):

- the capacity to synthesize and analyze;

- the capacity to organize and plan;

- critical and self-critical skills;

- the ability to work autonomously;

- decision-making skills.

Participative competencies foster civic commitment and the practice of active and responsible citizenship. The following competencies have been highlighted in particular (DeSeCo, 2003; Official Journal of the European Union, 2006; Government of Navarre, 2006; González and Wagenaar, 2003; NCREL, 2001; Partnership for 21st Century Skills, 2003):

- communication skills: oral and written communication;

- negotiation skills;

- problem and conflict resolution;

- initiative;

- teamwork, cooperation and interpersonal skills.

In light of this description of the contents of the social and civic competence, a brief account of the process by which it is acquired may also be relevant. As a set of habitual behaviors, the development of any competence is the outcome of the acquisition and consolidation of certain knowledge, attitudes and abilities whose overall purpose is personal, social and professional development, in such a way as to enable the citizen's active presence and participation in the knowledge society. Teaching, orientation and training are the means by which such aspects are to be fostered, respectively (Cardona, 2003; Cardona and García-Lombardía, 2005; Gómez-Llera and Pin, 1993; Hoskins and Crick, 2010; Lange, Print, Hoskins, et all, $2011)^{4}$.

Knowledge is acquired by obtaining new data and information; theoretical knowledge of any given competence facilitates its development.

Attitudes comprise the individual's motivations with respect to action, and are cultivated via an educational process. The goal of this process is to foster certain habits among students: that is, to enable them to make decisions based on what is 
best, rather than on what may seem most appealing to them. The overall objective is to bring the individual's affective motivation into line with rational motivation. This endeavor calls for an attitude of commitment to competence acquisition on the student's part.

Abilities are the operative skills required to ensure that the decisions taken are then enacted in practice. The acquisition of the operative skills pertinent to a particular competence is based on appropriate training: the repetition of specific actions.

Service-learning methodology may play a key role in acquiring the knowledge, attitude and skills needed for social and citizen competence. On the basis of the conceptual account of competence outlined above, the content of two service-learning programs implemented at secondary level, whose purpose is to foster the development of intellectual and participative civic competencies, is presented and assessed.

The decision to focus on secondary education may be explained clearly as follows: as the experience of educational practice attests, secondary level is the educational stage in which there is a particular regard for the development of civic-mindedness and of civic competencies. This is when the students first begin to more clearly understand that their individual actions have repercussions on society. In addition, they are more aware of the problems in their surroundings and the rest of the world, and of other people's needs. In a few short years they will also have the right to vote, which is one of the most fundamental means citizens have to direct life in their country. For these and many other reasons, secondary education is a particularly appropriate time to channel and form that budding civic responsibility which it stirs up in young people.

\section{THE DEVELOPMENT OF CIVIC COMPETENCIES. DESCRIPTION AND ASSESSMENT OF SERVICE-LEARNING PROGRAMS}

Service-learning is a pedagogical approach designed to find particular ways of involving students in the everyday life of the communities, neighborhoods and towns around the school they attend. In general terms, service-learning is a teaching methodology that emphasizes, in equal measure, academic learning in the classroom and voluntary involvement in service in response to the needs of the immediate community, thus enabling the mutual enrichment of both dimensions and rendering them an indivisible whole (Battle, 2009; Puig et al., 2006; Ugarte and Naval, 2010b).

Service-learning evokes the importance of personal commitment in social affairs, the need to be able to count on responsible, active citizens. This commitment goes from paying taxes to voting or involvement in social issues (Battle, 2009).

Service-learning may be distinguished from similar - though not identical initiatives such as voluntary work by reference to a series of criteria, as follows (Martínez-Odria, 2005, Sigmon, 1994):

a. The preeminent role of the student's voice. The teacher guides the learning process and encourages initiative, but the students themselves identify the community's needs and decide on the projects to be undertaken. 
b. Focus on a real need in the community. Student participation enables them to engage as active citizens and furnishes them with the tools required to function in the context of their community. A range of resources may be availed of in determining the community's needs: local newspapers, surveys, interviews, a list of student concerns regarding community life, etc.

c. Link to the learning objectives in the curriculum. Unlike voluntary work projects, which prioritize the service carried out, the service-learning methodology regards the service activity and the learning objectives as equally important.

d. Implementation of a service project. Neither project design nor social analysis is enough; the project must also be put into practice.

e. Reflection. Critical thinking skills are put into practice in preparing and carrying out the project, so as to learn from it. This process ensures that meaningful interrelations may be traced between the experience of voluntary service in the community and curriculum-based learning objectives.

Service-learning began in the US in the 1960's and 1970's. This was when it became clear that there was general unease with the course taken by the system of education, which was finding it difficult to give valid answers to new social demands. The sociologist Putnam's analysis was particularly influential as it showed a greater than ever drop in citizens' civic involvement. The generalization of the term ServiceLearning, in contrast with other socially recognized pedagogical proposals, had its origins in the Campus Compact (a coalition of college and university presidents who are aware of the importance of promoting the development of citizenship values and skills among students, through community service) which, shortly after its creation in 1985 , began to use it regularly in its publications. From then on, it spread to other colleges and universities all over the country. The 90's witnessed an explosion in the development of Service-Learning, which now has explicit institutional support.

No European country has adopted the American Service-Learning initiatives as is; they have preferred to adapt this methodology to the educational and social needs of their specific reality, which fact enriches and gives a broader range of nuances to the program. An important milestone in the spread of Service-Learning in Europe is the CIVICUS research project, which aims to explore the forms and strategies of cooperation between universities, corporations, the Civil Service and community organizations ${ }^{5}$.

In 2002 the British government set up a funding system to promote community service initiatives. In Britain the proposal and enactment of voluntary community service and citizen participation are to be found in the debate on citizenship, which is part of the national curriculum.

In Spain, the idea of promoting Service-Learning projects in schools began in 2001, thanks to contacts made by the Spanish Volunteer Association (Asociación Española del Voluntariado) with American Experts on the methodology. The official presentation of the Service-Learning project occurred in 2002, although the term used was Community Service Learning, and institutional contacts were established 
to gain Ministerial support for the proposal. In 2003, the Higher Teacher Training Institute (Instituto Superior de Formación del Profesorado) ecognized and registered the activity of Teacher Training in the Service-Learning methods.

Generally speaking, we could say that there is widespread agreement on the urgent need to train students in the values of citizenship. This training must be based on authentic, specific experience and not be limited to the communication of theoretical contents. However, the term Service-Learning was unheard of until very recently and even nowadays is not well-known.

Having finished this summary on the Service-learning concept, we will now deal with two specific experiences of Service-learning carried out in the UK and the US: Building People Voice and Voices of Freedom. The objective of these two experiences is to educate for social and citizen competence. The two initiatives are described in terms of objectives, features, methodology, proposed activities and assessment. Following this description, the programs are assessed in relation to which of the intellectual and participative competencies outlined above are successfully carried out The following is an analysis of these programs.

\section{A Service-learning experience in the United Kingdom: Building People Voice}

The Building People Voice program is being developed and promoted by the Association for Citizenship Teaching (ACT). The aim of the ACT is to offer support to teachers to deliver citizenship education. Moreover, it equips young people with the skills and knowledge to exercise their democratic responsibility and engage in public life ${ }^{6}$.

This organization promotes different secondary education civics programs, among which we find Building People Voice, Making Sustainability a Reality and Where does our food come from? ${ }^{7}$

Here we will analyze the content of Building People Voice.

\section{A. Objectives}

A1. The general objective of this program is to stimulate pupil participation in the school community. The concrete proposal is to improve the center's School Council. The aim is to give the pupils a voice on issues that affect the school community and give feedback on the decisions taken.

A2. The following specific objectives to be reached by the pupils are mentioned:

- Understanding democracy as a type of government.

- Arousing interest in participation in the school community and in the political life of the school.

- Fostering the right to political participation, more specifically, the right to vote.

- Raising pupils' awareness that their opinion counts and that their proposals help to improve the school.

- Developing knowledge and understanding of what it means to be a member of a democratic School Council. 
- Cultivating the competencies needed to increase participation in the school council.

- Improving the way opinions are transmitted within the school.

B. Characteristics

B1. The program has been developed and applied in Baverstock School, Birmingham, since 2006. Baverstock is an area with a low social-economic level, which suffers from a lack of social cohesion and the sense of a disintegrating community.

B2. The program was designed for secondary school students between the ages of 11 and 18.

B3. The area in which the program is applied is the classroom.

C. Methodology

The following methodology is proposed to reach the program objectives:

1. Elections are held to choose the students who will be members of the School Council.

2. Once elected, the teacher meets the student representatives and they debate the issues to be dealt with by the Council.

3. The following methods are used to keep the students informed of the work done in the Council meetings:

a. The dates of Council meetings are advertised in the school calendar.

b. A notice board to advertise the work of the Council and the decisions taken.

c. The Council minutes are published on the school website, which also gives information of the dates when the Pupil Voice Week will be held.

4. In order to transmit general information on the project, the following are used:

a. The weekly school newsletter, where the actions carried out in the project framework are published.

b. Posters advertising the aims of the program.

c. The school radio station which allows pupils to express their opinions. During the Pupil Voice Week there is a special program themed on these activities.

5. The Pupil Voice Week is a means for students, teachers, parents/guardians and other members of the school community to express their opinions on matters of interest for the community. The means used is the assembly.

D. Activities

Within the program framework, the students carry out various activities in order to reach their aims. These are:

a. Attending classes on citizenship.

b. Involvement in the assemblies.

c. Participation in the election of classmates as their representatives on the Council.

d. Contribution of their opinions on possible actions to improve the school during Pupil Voice Week. 


\section{E. Assessment}

Both the teachers and the pupils consider the program positively, mainly the Pupil Voice Week. However, when evaluating the program, they do say that this is a new initiative and, therefore, will be improved little by little.

Specifically, the students taking part in this program obtain the following learning results:

- Understanding of the workings of the School Council.

- Knowledge of a fair, democratic electoral process.

- Appreciation of the value of expressing their opinions as a means to influence improvement in the school community.

- Awareness of their responsibility in contributing through their proposals to the improvement of the school.

- Active participation in improving the school.

- They learn that the School Council is an effective means to channel their proposals for school improvement.

Having described this teaching experience, we will now go on to analyze the contents of the second program: Voices of Freedom

\section{Description of a Service-Learning experience in the United States: Voices of Freedom}

Voices of Freedom is a program sponsored by the National Service-Learning Clearinghouse (NSLC). This organization offers support to schools to implement Service-Learning methodology at different educational levels ${ }^{8}$. The NSLC promotes primary school programs such as Veterans, Trash to Treasure, Micro Society at Riverside Elementary or Donate a Quilt. At the secondary level, apart from the program analyzed here, they develop others such as S.T.A.R.T., Good Deeds, Energy Express: Putting Books in the Hands of Children, A Collective Bargaining Simulation and Activity Bags for Hospitalized Children'.

The following is the content of the Voices of Freedom Project.

A. Objectives

In the subject "History of the United States", during the study of the Civil Rights movement in the 1950's and 1960's, an opportunity was espied to invite local activists who were directly involved in the movement. The aim is to make the students realize that social change does not only come about in the highest political circles or is promoted by very influential, charismatic people -such as Martin Luther Kingbut that it demands direct citizen participation, and therefore, they have a direct responsibility for the support of social justice in their own surroundings. Within this framework of reference, the program has the following objectives:

1. To develop students' awareness of the role played by local activists in the Civil Rights movement in the 50's and 60's. 
2. To teach the students that ordinary people take part in great social movements when they stand up for a just cause.

3. To promote the involvement of the students in the struggle against injustice.

4. To promote and improve decision-making, initiative and the proactive attitude of the students.

B. Characteristics

$\mathrm{B} 1$. The program is designed for $11^{\text {th }}$ Grade students.

B2. In order to develop the program they had the assistance of various people and community institutions:

- the Local Chapters of the NAACP ${ }^{10}$

- the National Urban League ${ }^{l 1}$

- the California African-American Museum

- the African-American Studies Departments of local universities

B3. The area in which the program is applied is the classroom.

C. Methodology

The methodology used to reach the program objectives is as follows:

1. Lectures on the subject.

2. Study of the program.

3. Organization of an assembly. To apply the theoretical contents, the students participate in the organization of an assembly where local activists recount their experiences. To do so, they must work as a team. Each student is assigned tasks, respecting their differences. Equal participation of all the group members is promoted so that everyone makes significant contribution to the Project. Details of this action are specified in the section on "Activities".

D. Activities

The activities carried out within the framework of this program are theoretical and practical. Firstly, the students attend lectures where the teachers explain the most relevant events in the Civil Rights movement in the 50's and 60's. Later, the students -with the teacher's guidance- decide which the most significant citizen participation events were.

Once they have enough background information, the students organize the assembly with the local activists. The tasks they carry out are as follows:

1. They settle on what events in the Civil Rights movement they wish to hear more about.

2. They determine time, date and place of assembly, and how long it should last.

3. They decide the best way to contact the speakers who will participate in the project.

4. They find the location for the assembly.

5. They prepare a brief biography of each speaker to hand out at the session. 
6. They present the assembly and the speakers.

7. The speeches in the assembly are taped. When the activity is finished, this tape will become part of the school library collection.

8. They send thank-you notes to the activists who participate in the activity.

9. They write a reflective essay on their experiences.

E. Evaluation

After the application of the program the students show the following learning results:

- They improve their knowledge of the Civil Rights movement.

- They develop their oral and written communication skills:

a) Oral communication to contact the speakers and present them on the assembly day.

b) Written communication to successfully compose the essay with their feelings about the learning experience and to write the thank-you letters to the speakers.

- They improve their organizational and team-work skills by coordinating the assembly.

\section{Assessment of the Building People Voice and Voices of Freedom programs}

As has already been stated, the decisive value of the programs will be evaluated by attending to the formative value of the programs in as much as they help to develop those intellectual and participative competencies which are thought to be indispensable. The following chart gives details of this aspect.

Insert table 2

It is as well to explain that in the specific case of Building People Voice the leadership and initiative competencies will be developed in the pupils only if they themselves chose to stand for election to the School Council. Without this proactive attitude, the initiative would be impossible. On the subject of leadership, even if the pupils were not initially candidates, it may be developed during the performance of the post. On communication skills, we must highlight that oral communication skills are directly developed through debates and the Pupil Voice Week. Skills in writing will be fostered if and when the student participants on the program are entrusted to set up the calendar of events, the advertising on the notice-board and online, the newsletter and the content of the posters.

We can conclude by saying that the students who take part in these programs develop intellectual and participative skills. These initiatives are not the only way to develop these competencies, but they are an efficient means which helps with student civic learning. Specifically, more than social action such as attention to disadvantaged groups or cooperation for social and sustainable development, these learning experiences encourage political participation, which is another type of social action. 
Political participation is another course for involvement in community progress, either through the election of political representatives -who take decisions that have greater or lesser effects on society- or through participation in various associations of a political nature. Both of these actions are a way of giving a voice to the citizen in democracy. On this point, through school participation and the exercise of the right to vote within the school or through awareness, these programs allow the students to understand that society is built on the contributions of each and every citizen.

\section{CONCLUSIONS}

Currently, the use of the term competencies is widespread in all types of educational institutions. Both in business organizations and at the different levels of education, from obligatory to higher education, the different training actions carried out are based on competencies.

The development of social and citizenship competency is part of every student's training as academic and social excellence is part of the integral education of the individual. Therefore numerous international, European and Spanish initiatives mention the need to develop social and citizenship competency as one of the basic skills to be learned in obligatory education.

Social and citizenship competency is taken as meaning the knowledge, attitudes and skills that allow people to be concerned about social matters, to be convinced that democratic responsibility lies with citizens and social initiative. This conviction does not appear spontaneously, so education is needed. Secondary education is a particularly suitable educational stage for learning social and citizenship competency.

Social and citizenship competency implies the use of intellectual and participative competencies. In order to develop such competencies, gaining knowledge, arousing attitudes that favor action and the existence of skills that permit their efficient use are required. Service-learning is presented as a particularly appropriate methodology for the acquisition of the knowledge, attitudes and skills which are characteristic to this competency.

Building People Voice and Voices of Freedom are Service-learning programs that assist in the development of students' intellectual and participative skills. These programs attempt to transmit the idea that the direction of society or of a school does not depend exclusively on political or school organization measures in the hands of politicians or school managing bodies. Participation is everyone's business, and social improvement and the improvement of our surroundings are the responsibility of each and every one of us.

\section{NOTES}

Cfr. Ugarte, C. and Naval, C. 2010a, 2008a and 2008b.

This review of the inclusion of the social and civic competence in international, European and Spanish reports is based on Gavari, E. and Lara, S. (2010) "Focusing on competencies in the education of $21^{\text {st }}$ 


\section{NAVAL AND C. UGARTE}

century citizens" in Naval, C.; Lara, S; Ugarte, C. and Sádaba, C. Educar para la comunicación y la cooperación social. Pamplona: COAN, pp. 33-53.

3 Other basic competencies encompassed by the law are linguistic communication, mathematics, knowledge and interaction with the physical world, dealing with information in the digital era, cultural and artistic competence, learning to learn, and personal autonomy and initiative (Government of Navarra, 2006).

4 A more wide-ranging account from a pedagogical perspective of the process by which competencies may be acquired is given in Ugarte, C. and Naval, C. 2010a, 2008a and 2008b.

5 Further information at: http://www.civicus.org/ (Accessed March 2011).

6 Further information on this association at: http://www.teachingcitizenship.org.uk/

7 The full contents of these programs is available at: http://www.teachingcitizenship.org.uk/case studies

8 Further information on this organization at: http://www.servicelearning.org/

9 These programs may be consulted on the website of the National Community Service-Learning Clearinghouse at: http://www.servicelearning.org/.

10 Further information: http://www.naacp.org/content/main/

11 Further information: http://www.nul.org/

\section{REFERENCES}

Alles, M. (2008). Dirección estratégica de recursos humanos: gestión por competencias (Recurso electrónico). Buenos Aires: Granica.

Alles, M. (2000). Dirección estratégica de recursos humanos: gestión por competencias. Buenos Aires: Granica.

Battle, R. (2009). En servicio en el aprendizaje servicio. en J. M. Puig, (coord.), Aprendizaje servicio (ApS). Educación y compromiso cívico (pp. 71-90). Barcelona: Grao.

Boyatzis, R. (1982). The competent manager. New York: John Wiley \& Sons.

Cardona, P. (2003). El coaching en el desarrollo de las competencias profesionales. En M. Villalonga (coord.), Coaching directivo: desarrollando el liderazgo. Fundamentos y práctica del coaching (pp. 149-152). Barcelona: Ariel empresa.

Cardona, P., \& García-Lombardía, P. (2005). Cómo desarrollar las competencias de liderazgo. Pamplona: Eunsa.

Cardona, P., \& Chinchilla, N. (1999). Evaluación y desarrollo de competencias directivas. Nota técnica. Barcelona: IESE.

Conference of European Ministers Responsible for Higher Education, Bergen (19-20, May 2005). Retrieved from http://www.bologna-bergen2005.no/ [2007, noviembre]

Conference of Ministers Responsible for Higher Education, London (16-18 May, 2007). Retrieved from http://www.usal.es/ ofeees/DOCUMENTOS_INTERES/2007-comunicado-londres.pdf [2007, noviembre]

Delors, J. (coord.). (1996). La educación encierra un tesoro/informe a la UNESCO de la Comisión Internacional sobre la Educación en el siglo XXI. Santillana: Madrid.

DeSeCo. (2003). Definition and selection of key competencies - Executive summary. Retrieved from http://www.deseco.admin.ch/bfs/deseco/en/index/02.parsys.43369.downloadlist.2296. DownloadDile.tmp/2005.dskcexecutivesummary.en.pdf] Accedido: septiembre de 2008

Diario Oficial de la Unión Europea. (2006). Recomendación del parlamento Europeo y del Consejo de 18 de diciembre de 2006 sobre las competencias clave para el aprendizaje permanente (2006/962/CE).

Gavari, E., \& Lara, S. (2010). El enfoque de competencias en la educación del ciudadano del siglo XXI. In C. En Naval, S. Lara, C. Ugarte, C. y Sádaba (Eds.), Educar para la comunicación y la cooperación social (pp. 33-53). Pamplona: COAN.

Gobierno de Navarra. (2006). Las competencias básicas. La escuela que necesitamos. Retrieved from [http://orientacionandujar.files.wordpress.com/2010/01/competencias-basicas-la-escuela-quenecesitamos-gobierno-de-navarra.pdf] Accedido: mayo de 2010 
González, J., \& Wagenaar, R. (2003). Tuning educational structures in Europe: Informe final, fase uno. Bilbao: Universidad de Deusto.

Hoskins, B., \& Crick, R. D. (2010). Competencies for Learning to Learn and Active Citizenship: Different currencies or two sides of the same coin? European Journal of Education, 45(1), Part II, 121-137.

Jover, G., Fernández-Salinero, C., \& Ruiz Corbella, M. (2005). El diseño de titulaciones y programas ante la convergencia europea. En V. Esteban Chapapría (Ed.), El Espacio Europeo de Educación Superior (pp. 27-93). Valencia: Editorial de la Universidad Politécnica de Valencia.

Kerr, D. (2011). The curriculum and its application in building democratic citizenship in Europe. International Civic Education Symposium. An International Symposium on Building Democratic Citizenship in Europe through Young Civic Engagement in Schools. Leibniz Universität Hannover. Hannover, 18-20 April, 2011.

Lange, D., Print, M., Hoskins, B., et al. (2011). Basic text for discussion. International Civic Education Symposium. An International Symposium on Building Democratic Citizenship in Europe through Young Civic Engagement in Schools. Leibniz Universität Hannover. Hannover, 18-20 April, 2011.

Lara, S. (2008). Las competencias básicas necesarias para los ciudadanos del s. XXI: Una revisión de los principales estudios internacionales. En. Comunicaciones del XIV Congreso Nacional y III Iberoamericano de Pedagogía (pp. 1699-1707). Zaragoza: Sociedad Española de Pedagogía.

Le Boterf, G. (1993). Cómo gestionar la calidad de la formación. Barcelona: Aedipe y Gestión 2000.

Levy-Leboyer, C. (1997). Gestión de las competencias: cómo analizarlas, cómo evaluarlas, cómo desarrollarlas. Barcelona: Gestión 2000.

Ley Orgánica 2/2006, de 3 de mayo de Educación.

Martínez-Odría, A. (2005). Service-Learning o aprendizaje-servicio: Una propuesta de incorporción curricular del voluntariado. Thesis Doctoral. Universidad de Navarra (inédita).

Naval, C. (2000). Educación y derechos humanos. Humana Iura, 10, 43-59.

NCREL. (2002, Spring). The Engauge 21st Century Skills. North Central Region Education Laboratory Partnership for 21st Century Skills (2003, 2009) Learning for the 21st Century. A report and Mile Guide for 21st Century Skills, Partnership for 21st Century Skills. Retrieved from [http://www.p21. org/] Accedido: mayo de 2010

Pereda, S. (2006). Técnicas de gestión de recursos humanos por competencias. Madrid: Editorial Universitaria Ramón Areces.

Puig, J. M. y otros. (2006). Aprendizaje-servicio. Educar para la ciudadanía. Barcelona: Octaedro.

Real Decreto. (1393/2007). de 29 de octubre de 2007 por el que se establece la ordenación de las enseñanzas universitarias oficiales. BOE $\mathrm{n}^{\circ} 260$, de 30 de octubre de 2007.

Sarramona, J., Domínguez, E., Noguera, J., \& Vázquez, G. (2005). Las competencias en secundaria y su incidencia en el acceso a la universidad. En V. Esteban Chapapría (Ed.), El Espacio Europeo de Educación Superior (pp. 199-248). Valencia: Editorial de la Universidad Politécnica de Valencia.

Sigmon, R. L. (1994). Linking service with learning. Washington, DC: Council of Independent Colleges.

Ugarte, C., \& Naval, C. (2010a). Desarrollo de competencias profesionales en la educación superior. Un caso docente concreto. Revista Electrónica de Investigación Educativa [Núm. Especial]. Accedido enero 2001. Retrieved from http://redie.uabc.mx/contenido/NumEsp2/contenido-ugarte.html

Ugarte, C., \& Naval, C. (2010b). La formación política de los alumnos de educación secundaria. Descripción y valoración de programas de Service-learning en los Estados Unidos y en la Unión Europea. Edetania, 37, 109-128.

Ugarte, C., \& Naval, C. (2008a). Formación en competencias profesionales. Una experiencia docente online-presencial. Estudios sobre Educación, 15, 53-86.

Ugarte, C., \& Naval, C. (2008b). El profesor-tutor en una experiencia docente online-presencial. En G. Jover y D. Reyero (coords.), Teoría de la Educación: Educación y Cultura en la Sociedad de la Información, 9(1), 153-179. Monográfico: Enseñanza virtual, innovación e internacionalización de la educación. Retrieved from http://www.usal.es/ teoriaeducacion/rev_numero_09_01/naval.pdf (accedido: febrero 2008).

Veldhuis, R. (1997). Educación para la ciudadanía democrática: dimensiones de la ciudadanía, competencias esenciales, variables y actividades internacionales. Consejo de Europa: Consejo para la Cooperación Cultural (DECS/CIT (97) 23). 
Woodrufe, C. (1993). Assessment centres: Identifying and developing competentes. London: Institute of Personal Management.

\section{ONLINE RESOURCES FOR FURTHER INFORMATION}

Canada:

Rubric for Assessing Quality of the Service-Learning Experience: Wisconsin Department of Public Instruction http://dpi.state.wi.us/fscp/pdf/sl-qual-rubric.pdf

United States of America

Learn and Serve America's National Service-Learning Clearing House:

http://www.servicelearning.org/

European Union

Politeia: http://www.politeia.net

Citized: http://www.citized.info

Association for Citizenship Teaching (ACT): http://www.teachingcitizenship.org.uk

Networking European Citizenship Education (NECE): http://www.bpb.de/veranstaltungen/ PAJZMN,0,NECE_Networking_European_Citizenship_Education.html 